\title{
Effect of Promotion and Ease of Use on Customer Satisfaction and Loyalty on OVO Application Users
}

\author{
Fajar Tangguh Anugrah* \\ Faculty of Economics anda Business, Narotama University, Surabaya, Indonesia, tangguhfajar@gmail.com
}

\begin{abstract}
The development of a business that is currently globally quite rapid happening, this is related to the development of increasingly advanced technology, especially those based on the internet. Technological developments in Indonesia have also increased rapidly, one of which is changing daily activities is the payment system, where the circulation of cash is not as much as before. Non-cash payments are currently widely used by the public to transact, from debit card debit, e-money credit cards, and payment by applications through smartphones. With the emerging payment trend like that, many big companies are competing to create the same system, for example the largest network company in Indonesia, Telkomsel with its T-Cash, gojek by creating its Gopay and also recently emerged. with a promotional offer that interets Indonesian consumers is OVO. The purpose of this study was to analyze the effect of promotion and ease of use on customer satisfaction and loyalty. This type of research is quantitative. The study population was 100 respondents who used the OVO application in Surabaya. The analysis technique used is Partial Least Square (PLS). Data obtained from questionnaires and tested with the SmartPLS 3.0 application. The results of this study indicate that promotion and ease of use have a significant effect on customer satisfaction and customer loyalty. And customer satisfaction has a positive and significant impact on customer loyalty.
\end{abstract}

Keywords :Promotion, Ease of Use, Customer Satisfaction, and Customer Loyal

\section{Introduction}

The development of a business that is currently globally quite rapid happening, this is related to the development of increasingly advanced technology, especially those based on the internet. The development of technology in Indonesia itself is also increasing rapidly from day to day and from year to year, this can be influenced by various factors ranging from expanding internet coverage, increasing internet bandwidth, using internet technology and communication which is faster and more considered efficient, the development of smart phones is able to bring up various kinds of social media and ecommerce, as well as the increasing number of people who understand and actively use the internet. With our inclusion in the 4.0 business revolution, all jobs are good, for example manufacturing, services, and health also entering this era where everything is very easy, fast, effective, efficient, and even more so with costs that can be pressed to be cheaper by using technology application. One of them is that changing daily activities is the payment system, where the circulation of cash is not as much as before. Non-cash payments are currently very much used by the public to make transactions. Starting from the debit card, credit card, emoney, and by using the payment application via smartphone. With the emerging payment trend like that, many big companies are competing to create the same system, for example the largest network company in Indonesia, Telkomsel with its T-Cash, gojek by creating its Gopay and also recently emerged. with a promotional offer that interests Indonesian consumers is OVO.

According to the results of the Financial Times Confidential Research Mobile Payment, the Go-pay service found first order as the most popular e-money and most used by the people of Indonesia, amounting to 50\%, Then the second sequence was OVO with $40 \%$ results, Next T-Cash amounted to finding the order third is $30 \%$, then BCA KlikPay found the fourth place which is $25 \%$, and finally DOKU Wallet is $5 \%$. Loyalty is a customer's attitude in the

\footnotetext{
* Corresponding author.

E-mail address: tangguhfajar@gmail.com (Fajar Tangguh Anugrah)
} 
form of commitment, and not all customers form loyalty to certain products or services for various reasons. In general, companies must avoid the target of no loyalty because it will experience difficulties in forming loyal customers and will weaken the company, so various marketing strategies are carried out to retain consumers for example by providing various promotions that can have an impact on customer loyalty. One of the special characteristics of customer loyalty is that they make regular and repetitive purchases, even they voluntarily recommend the advantages of the products or services that the company has.

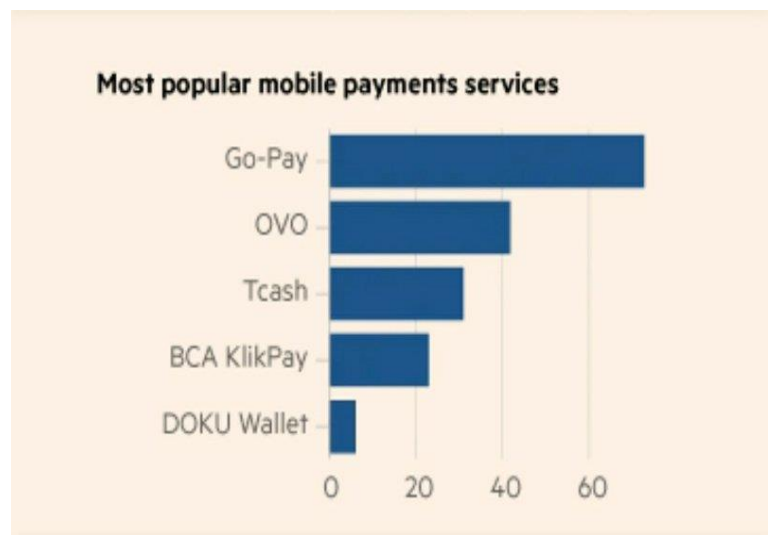

Figure 1. The most popular electronic money in Indonesia

\section{Literature Review}

\section{a. Promotion $(X 1)$}

General terms, promotion is defined as a one-way flow of information or persuasion created to direct a person or organization to actions that create exchanges in marketing (Swastha, 2007). Promotion is a broad-based expression of activities or activities that are effectively carried out by companies (sellers) to encourage consumers to buy the products or services offered (Sukirno, Zakaria, \& Poerwanto, 2014)

This study explores the effect of promotion on customer satisfaction and customer loyalty, using promotional indicators according to (Philip, 1997) : Reach of Promotion, Quantity of ad serving in promotional media, quality of delivery of messages in ad serving in promotional media

Hypothesis 1: promotion has a significant effect on customer satisfaction

Hypothesis 2: promotion has a significant effect on customer loyalty

\section{b. Ease of Use}

According Jogiyanto (2007) Ease of Use is also defined as the extent to which someone believes that using a technology will be free from effort. According Davis, Bagozzi, \& Warshaw (1989) ease of use is defined as the degree to which a person believes that the use of information technology is easy and does not require the effort of the wearer.

This study explores the effect of ease of use on customer satisfaction and customer loyalty, using the following indicators:

1) Clear and easy to understand (Davis et al., 1989).

2) Easy to use expertly (Davis et al., 1989). 
3) Flexible (Davis et al., 1989).

4) Easy to learn (Irawan, 2002)

5) Time efficiency (Irawan, 2002)

Hypothesis 3: ease of use has a significant effect on customer satisfaction

Hypothesis 4: ease of use has a significant effect on customer loyalty

\section{c. Customer Satisfaction}

Satisfaction is a feeling of pleasure or a disappointment that arises after comparing between perceptions or impressions of the results obtained and can also be a product performance in accordance with expectations (Cateora, 2002). Consumer satisfaction has a positive effect on loyalty and simultaneously consumers are satisfied (Kurtz, D.J and Clow, 1993).

This study explores the effect of ease of use on customer satisfaction and customer loyalty, using the following indicators:

1) Confirmation of expectations (Tjiptono, 2005).

2) Interest in purchasing (Tjiptono, 2005).

3) There are no complaints about the product (Pratiwi, 2010).

4) Customer satisfaction on the whole product (Pratiwi, 2010).

Hypothesis 5: customer satisfaction has a significant effect on customer loyalty

\section{d. Customer Loyalty}

According to (Hasan, 2008)argues that customer loyalty is a person who buys, especially those who buy regularly and repeatedly. A customer is someone who constantly comes to the same place to satisfy his needs and desires by owning a product or service and paying for both. A loyal customer has specific prejudices about what to buy and from whom. The buyer is not a random event. In addition, loyalty indicates the condition of the time duration and requires that the action be less than twice (Griffin, 2003)This research explores the effect of promotion on customer satisfaction and customer loyalty, by using indicators of customer loyalty according to (Griffin, 2005): Conduct repeat research, be able to influence others, and demonstrate resistance to competing products or services.

\section{e. Research Framework}

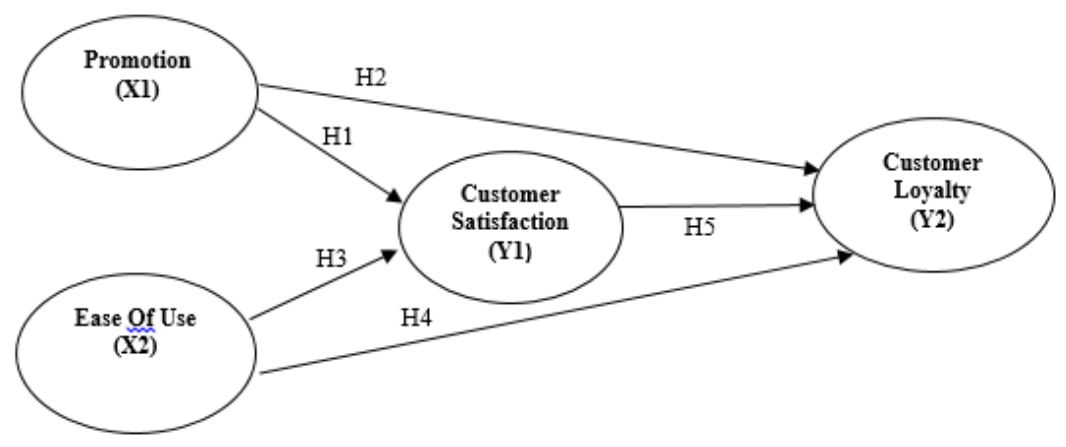

Figure 2 : Research framework 


\section{Metodology}

Research using a quantitative approach is a method based on the philosophy of positivism, used to examine populations or specific samples, data collection using research instruments, quantitative / statistical data analysis, with the aim of testing established (Sugiyono, 2008). The variables of this study consisted of independent variables namely promotion and ease of use. Intervening variable is customer satisfaction. And the dependent variable is customer loyalty. The population in this study are customers who use the OVO application in Surabaya, as many as 100 respondents. Data analysis techniques using Partial Least Square (PLS) with SmartPLS 3 software.

\section{Result And Discussion}

R-Adjusted customer satisfaction variable of 0.636 this result shows that the free variable promotion and ease of use contributed $63.6 \%$ to customer satisfaction and the remaining $36.4 \%$ is influenced by other factors, while for the customer loyalty variable R-Adjusted of 0.620 this result shows that the independent variable promotion and ease of use contributed $62 \%$ and the remaining $38 \%$ was influenced by other factors.

In testing hypotheses, a data must meet a criterion, and the hypothesis is said to be accepted if the t-statistic value is greater than t-table $(1,660)$ and if the $p$-value is less than 0.05 and vice versa.

The SmartPLS output results are as follows:

Table 1. Path Coefficient

\begin{tabular}{lcc}
\hline \multicolumn{1}{c}{ Path Coefficient } & t-statistic & p-value \\
\hline Promotion (X1) -> Customer Satisfaction (Y1) & 3.880 & 0.000 \\
Promotion (X1) -> Customer Loyalty (Y2) & 4.175 & 0.000 \\
Ease Of Use (X2) -> Customer Satisfaction (Y1) & 9.974 & 0.000 \\
Ease Of Use (X2) -> Customer Loyalty (Y2) & 2.742 & 0.003 \\
Customer Satisfaction (Y1) -> Customer Loyalty (Y2) & 2.973 & 0.002 \\
Promotion (X1) - > Customer Satisfaction (Y1) -> Customer & 2.236 & 0.013 \\
Loyalty (Y2) & & \\
Ease Of Use (X2) - > Customer Satisfaction (Y1) -> & 2.743 & 0.003 \\
Customer Loyalty (Y2) & & \\
\hline
\end{tabular}

\section{a. Direct Influence}

\section{Hypothesis 1: Effect of Promotion on Customer satisfaction}

Based on the results of the analysis it can be seen that the promotion has a positive and significant effect on customer satisfaction with the results of the p-value $0,000<0.050$ and the $t$-statistic value $>t$-table that is $3,880>1,660$.

The results of this study are supported by previous research conducted by (Gulla, Oroh, \& Roring, 2015) with the research title Analysis of Price, Promotion, and Service Quality on Consumer Satisfaction at the Manado Grace Inn Hotel. States that promotion simultaneously has a significant effect on customer satisfaction. Supported by previous research conducted by (Hatta, Rachbini, \& Derriawan, 2018) with the research title Brand Image Analysis, Promotion, Satisfaction and Customer Loyalty, states that promotion has a positive and significant effect on customer satisfaction. This shows that the better and more attractive promotions offered to consumers will create a feeling of customer satisfaction after making transactions using the OVO application.

\section{Hypothesis 2: Effect of Promotion on Customer Loyalty}

Based on the results of the analysis it can be seen that the promotion has a positive and significant effect on customer loyalty with the results of the p-value $0,000<0.050$ and the value of t-statistics $>t$-table is $4.175>1,660$. 
The results of this study are supported by previous research conducted by (Tatar, 2016) entitled Impact of Price, Distribution Channel and Promotion on Loyalty, which states that promotion has a significant effect on customer loyalty. And supported by research conducted (Rasmansyah, 2017) with the research section The effect of service quality and promotion to customer satisfaction and implication of customer loyalty in vehicle financing companies in Jakarta Indonesia, states that promotion has a significant effect on customer loyalty. Supported by previous research conducted by (Hatta et al., 2018) with the research title Brand Image Analysis, Promotion, Satisfaction and Customer Loyalty, states that promotion has a positive and significant influence on customer loyalty. This shows that the better and more attractive promotion that has been offered to consumers will create a feeling of customer satisfaction after using the OVO application and will cause consumer behavior to transact using the OVO application in a sustainable and repetitive manner.

\section{Hypothesis 3: Effect of Ease of Use on Customer Satisfaction}

Based on the results of the analysis it can be seen that ease of use has a positive and significant effect on customer satisfaction with the results of the $\mathrm{p}$-value $0,000<0.050$ and the $\mathrm{t}$-statistic value $>\mathrm{t}$-table is $9,974>1,660$.

The results of this study are supported by previous research conducted by (Antika \& Andjarwat, 2016) with the title research Effect of Ease and Emotional Factor on Word of Mouth with Satisfaction as Intervening Variables (Study of OLX Consumers in Surabaya) which states that ease has a positive and significant effect to customer satisfaction. And supported by research conducted by (Amin, Rezaei, \& Abolghasemi, 2014) with the research title User satisfaction with mobile websites: the impact of perceived usefulness (PU), perceived ease of use (PEOU) and trust, stating that ease of use has a positive and significant effect on satisfaction. This shows that the more easy to understand and effective use of the OVO application, it will create a feeling of customer satisfaction after using the services of OVO.

\section{Hypothesis 4 : Hypothesis 4: Effect of Ease of Use on Customer Loyalty}

Based on the results of the analysis it can be seen that the ease of use has a positive and significant effect on customer loyalty with the results of the p-value $0.003<0.050$ and the t-statistic value $>t$-table that is $2.742>1,660$.

The results of this study are supported by previous research conducted by (Nainggolan, 2018) entitled Influence of Satisfaction, Trust and Ease on Customer Loyalty of Pt Great Seasons Tours and Travel in Batam which states that ease has a positive and significant effect on customer loyalty. And supported by research conducted (Tu \& Linb, 2012) with the research title Perceived Ease of Use, Trust, and Satisfaction as Determinants of Loyalty in e-Auction Marketplace, states that satisfaction has a significant influence on customer loyalty. This shows that with the increasingly easy to understand and effective use of the OVO application it will create a feeling of customer satisfaction after using the services of OVO, so that it will create consumer behavior to use the services of OVO continuously and repeatedly.

Hypothesis 5: Effect of Customer Satisfaction on Customer Loyalty Based on the results of the analysis it can be seen that customer satisfaction has a positive and significant effect on customer loyalty with the results of p-value $0.002<0.050$ and $t$-statistics $>t$-table value of $2.973>1,660$.

This research is supported by previous research conducted by (Nainggolan, 2018) entitled Influence of Satisfaction, Trust and Ease on Customer Loyalty of Pt Great Seasons Tours and Travel in Batam which states that satisfaction has a positive and significant effect on customer loyalty. And supported by research conducted (Tu \& Linb, 2012) with the research title Perceived Ease of Use, Trust, and Satisfaction as Determinants of Loyalty in e-Auction Marketplace, states that satisfaction has a significant influence on customer loyalty. Supported by previous research conducted by (Hatta et al., 2018) with the research title Brand Image Analysis, Promotion, Satisfaction and Customer Loyalty, states that satisfaction has a positive and significant influence on customer loyalty. This shows that the more promotion programs that have been offered as well as making it easier for customers to use the OVO application, it will create a feeling of customer satisfaction so that it will create customer behavior to be loyal in using the services of the OVO application on an ongoing or repeated basis. 


\section{b. Indirect Influence}

1) Promotion (X1) on Customer Loyalty (Y2) through Customer Satisfaction (Y1)

Based on the results of the analysis it can be seen that the promotion of a positive and significant effect indirectly on customer loyalty through customer satisfaction. The results of the p-value $0.013<0.050$ and the value of t-statistics $>$ $\mathrm{t}$-table is 2.236> 1.660. This shows that the better and more attractive promotion that has been offered to consumers will create a feeling of customer satisfaction after using the OVO application and will cause consumer behavior to transact using the OVO application in a sustainable and repetitive manner.

\section{2) Ease Of Use (X1) on Customer Loyalty (Y2) through Customer Satisfaction (Y1)}

Based on the results of the analysis it can be seen that ease of use has a positive and significant effect indirectly on customer loyalty through customer satisfaction. The results of the p-value $0.003<0.050$ and the value of t-statistics $>$ t-table is $2.473>1.660$. This shows that with the increasingly easy to understand and effective use of the OVO application it will create a feeling of customer satisfaction after using the services of OVO, so that it will create consumer behavior to use the services of OVO continuously and repeatedly.

\section{Conclusion}

The findings of this study indicate that the direct influence of the promotion free variables and ease of use have a positive and significant effect on customer satisfaction and loyalty on OVO application users in Surabaya. Respondents agreed to the promotion and ease of use.

The promotion and ease of use variables have a positive and significant effect indirectly on customer loyalty through customer satisfaction.

\section{References}

Amin, M., Rezaei, S., \& Abolghasemi, M. (2014). User satisfaction with mobile websites : the impact of perceived usefulness ( PU ), perceived ease of use ( PEOU ) and trust. The Current Issue and Full Text Archive of This Journal Is Available. https://doi.org/10.1108/NBRI-01-2014-0005

Antika, B. W., \& Andjarwat, A. L. (2016). Pengaruh kemudahan dan emotional factor terhadap word of mouth dengan kepuasan sebagai variabel intervening (studi pada konsumen olx di surabaya), 4, 1-14.

Cateora, P. . (2002). International Marketing (Eleventh). New York: Mc Graw Hill.

Davis, F. D., Bagozzi, R. P., \& Warshaw, P. R. (1989). User Acceptance of Computer Technology : A Comparison of Two Theoretical Models User Acceptance Of Computer Technology: A Comparison Of Two, 38(September 2016). https://doi.org/10.1287/mnsc.35.8.982

Griffin, J. (2003). Customer Loyalty: Menumbuhkan Dan Mempertahankan Pelanggan. Jakarta: Erlangga.

Griffin, J. (2005). Costomer Loyalty : Menumbuhkan dan Mempertahankan Kesetiaan Pelanggan. Jakarta: Erlangga.

Gulla, R., Oroh, S. G., \& Roring, F. (2015). Analisis harga, promosi, dan kualitas pelayanan terhadap kepuasan konsumen pada hotel manado grace inn. Jurnal EMBAl E, 3(1), 1313-1322.

Hasan, A. (2008). Manajemen Pemasaran dan Marketing. Bandung: Alfabeta.

Hatta, I. H., Rachbini, W., \& Derriawan. (2018). Brand Image Analysis, Promotion, Satisfaction and Customer Loyalty. Journal of Business and Management (IOSR-JBM), 20(12), 50-55. https://doi.org/10.9790/487X2012055055

Irawan, H. (2002). 10 Prinsip Kepuasan Pelanggan. Jakarta: Gramedia.

Jogiyanto. (2007). Sistem Informasi Keperilakuan. Yogyakarta: andi. 
Kurtz, D.J and Clow, K. . (1993). Managing Consumer Expectation On service. Journal of Marketing Management, $2,19-25$.

Nainggolan, N. P. (2018). Satisfication, Trust, Choice Reduction and Habit, Customer's Loyalty ABSTRAK, 6(1).

Philip, K. (1997). Manajemen Pemasaran (Bahasa Ind). Jakarta: Prentice Hall.

Pratiwi, D. I. (2010). “Analisis Pengaruh Harapan Pelanggan, Kualitas Produk, dan Kepuasan Pelanggan Terhadap Loyalitas Pelanggan Internet Flash Unlimited di Semarang. Retrieved from https://core.ac.uk/download/files/379/11722037.pdf

Rasmansyah. (2017). The effect of service quality and promotion to customer satisfaction and implication of customer loyalty in vehicle financing company in Jakarta Indonesia. International Journal of Advanced Scientific Research.

Sugiyono. (2008). Metode Penelitian Kunatitatif Kualitatif dan R\&D. Bandung: Alfabeta.

Sukirno, Zakaria, \& Poerwanto. (2014). Kominikasi Bisnis. Yogyakarta: Pustaka Pelajar.

Swastha, B. (2007). Azas-Azas Marketing. Yogyakarta: Liberty.

Tatar, P. (2016). Impact of Price, Distribution Channel and Promotion on Loyalty Introduction: International Academic Journal of Psychology and Educational Studies, 1(2), 83-93.

Tjiptono, F. (2005). Pemasaran Jasa. Malang: Bayumedia Publishing.

Tu, C., \& Linb, K. F. and C.-Y. (2012). Perceived Ease of Use, Trust , and Satisfaction as Determinants of Loyalty in e-Auction Marketplace. Journal of Computers, 7(3), 645-652. https://doi.org/10.4304/jcp.7.3.645-652 